\title{
VITEX NEGUNDO EXTRACTS PROTECT HUMAN CORNEAL EPITHELIAL CELLS FROM ULTRAVIOLET C-INDUCED PHOTOTOXICITY
}

\author{
DEEKSHA $\mathrm{K}^{1,2}$, CYNTHIA ARUNACHALAM ${ }^{2 *}$ \\ ${ }^{1}$ Department of Ophthalmology Yenepoya Medical College, Yenepoya (Deemed to be University), Mangalore, Karnataka, India, ${ }^{2}$ Yenepoya \\ Research Centre, Yenepoya (Deemed to be University), Mangalore, Karnataka, India. Email: cynthiaarunachalam@yahoo.com
}

Received: 16 November 2018, Revised and Accepted: 18 December 2018

\section{ABSTRACT}

Objective: The objective of the study was to investigate the protective effects of Vitex negundo (VN) extracts against ultraviolet (UV) light C-induced oxidative stress in human corneal epithelial cells (HCEC) in vitro.

Methods: The VN extracts were checked for their antioxidant activities by biochemical tests. The preliminary phytochemical analysis was done to check the presence of secondary metabolites. To trigger oxidative stress, the HCEC were exposed to UVC irradiation $\left(200 \mathrm{~J} / \mathrm{m}^{2}\right)$. Then, different concentration of VN extracts was administered after $1 \mathrm{~h}$ of UVC irradiation. The effects of UVC irradiation and the extracts on the HCEC viability, morphology, cell migration by scratch assay, and reactive oxygen species (ROS) production by dichlorofluorescein diacetate method were measured.

Results: VN ethanol (VNE) extract showed the highest antioxidant activity than the aqueous extract. Phytochemical screening shows the presence of alkaloids, carbohydrates, proteins, phenolics, and tannins. The extracts showed no cytotoxicity on the HCEC and also the VNE extract did not alter the morphology of the cells. Results suggest that the VNE extract enhanced the proliferation and migration of HCEC. The VNE extract significantly decreased UVC-induced oxidative toxicity by inhibiting the intracellular ROS production and maintained cell viability.

Conclusion: VN extracts with its strong antioxidant potential protects HCEC from UVC-induced oxidative stress. The results suggest that these extracts can be used as prophylactic agents or as a therapeutic agent in overcoming UV light-induced damage in various ocular surface diseases such as pterygium and photokeratitis.

Keywords: Ultraviolet rays, Antioxidant, Corneal epithelium, Vitex negundo.

(c) 2019 The Authors. Published by Innovare Academic Sciences Pvt Ltd. This is an open access article under the CC BY license (http://creativecommons. org/licenses/by/4. 0/) DOI: http://dx.doi.org/10.22159/ajpcr.2019.v12i3.30792

\section{INTRODUCTION}

Cornea acts as a primary and structural barrier of the eye. The corneal epithelium is frequently exposed to ultraviolet (UV) radiation such as UVA $(315-400 \mathrm{~nm})$, UVB $(280-315 \mathrm{~nm})$ from the sun, and UVC (200-280 nm) through occupational exposures [1]. The cornea is known to absorb $100 \%$ of UVC without allowing them to penetrate further into the interior of the eye [2]. Thus, corneal epithelium is susceptible to UVC-induced damages. Imbalance in the antioxidant defense mechanism takes place during UV exposure leading to injury in the cornea and other parts of the eye [3]. Excessive exposure to these radiations leads to oxidative stress in the ocular surface cells resulting in epithelial exfoliation followed by extreme pain, a condition known as photokeratitis [4].

Reactive oxygen species (ROS) are formed during aerobic metabolism as metabolic by-products in which their levels are maintained in healthy cells through intrinsic antioxidant mechanisms in healthy cells. Abnormal redox homeostasis which involves overproduction of ROS will induce oxidative stress leading to the damage of the normal physiological condition [5]. Various studies have shown that ROS overproduction of ROS damage the stability of genome; enhance cancer progression [6,7]. In the cornea, ROS directly cleavage the stromal glycosaminoglycans and alter physiological properties, which leads to oxidative stress and sometimes in severe conditions leads to vision loss [8]. Medicinal plants are a potential source of natural antioxidants, and they are known to protect the cells from ROS-induced oxidative damages. Various medicinal plants possess constituents such as flavonoids, flavones, anthocyanins, lignans, and isocatechins which contribute to their antioxidant activity and their therapeutic potential $[9,10]$.
Vitex negundo (VN) is commonly known as a five-leaved chaste tree. It is used in different treatment systems such as Ayurveda, Unani, Siddha, Homeopathy, and Allopathy [11]. This plant possesses antiinflammatory, antioxidant, hepatoprotective, neuroprotective, and cardioprotective functions which can be attributed to their therapeutic potential [12-15]. Various therapeutic uses have been reported, VN leaf extract is used as an external application for treatment of mumps, wounds, and cuts. It is also used an external application for treating tonsillitis, congestion, and scabies along with other plant mixtures [16]. Apart from these medicinal properties, they are also indicated for Netra roga by Acharya Sushruta in Uttartantra as Anjana in Timira roga and Kapha Vidhagdha Dristi [17]. Different nighantus described this plant as Netrahita and chakshusya $[18,19]$.

Although there are many studies on the antioxidant activity of VN extracts, the potential for using these extracts in the treatment of eye disorders is not yet investigated. The effects of these extracts on UVCinduced injury in human corneal epithelial cells (HCEC) are yet to be evaluated. Hence, the present study aims to explore the protective effects of VN leaf extracts in preventing oxidative injury in HCEC and its antioxidant activity.

\section{METHODS}

\section{Plant-source and extract preparation}

The leaves of VN were collected from Yenepoya (Deemed to be University) Garden, Derlakatte, Mangalore and were identified by the botanist. The leaves were air-dried and grounded into a powder. Powdered samples were subjected to maceration using distilled water and ethanol for $24 \mathrm{~h}$ in a shaker incubator. The extracts were filtered using Whatman filter paper and concentrated using SpeedVac Concentrator. The dried extract was stored at $4^{\circ} \mathrm{C}$ until further use [20]. 
Phytochemical screening

The phytochemical evaluation was done for both aqueous and ethanol extracts using standard protocol [21].

\section{Estimation of antioxidant activity}

Total antioxidant capacity (TAC) assay by phosphomolybdate method

VN leaf extracts were evaluated for their antioxidant activity by phosphomolybdenum method [22]. This method determines the antioxidant activity through the formation of the phosphomolybdenum complex. The experiment was performed in triplicates against the standard ascorbic acid. The total antioxidant activity of the leaf extracts was expressed as ascorbic acid equivalents (AAE).

\section{1,1-diphenyl-2 picrylhydrazyl (DPPH) free radical scavenging activity}

Free radical scavenging ability of extracts was measured by the DPPH assay [23]. This is based on the ability of antioxidants to reduce the stable dark violet radical DPPH to the yellow colored diphenyl-picrylhydrazine. Plant extract at concentrations (50-600 $\mu \mathrm{g} / \mathrm{ml}$ ) was used for the experiment. Ascorbic acid was used as a standard for the free radical scavenging activity. The percentage radical scavenging activity was calculated using the formula given below,

\section{$\%$ Radicalscanvenging activity $=(\mathrm{Ac}-\mathrm{AE}) \times 100 / \mathrm{Ac}$}

Where,Ac is the Absorbance of Control (DPPH),AE is the Absorbance of test.

\section{Quantitative phytochemical screening}

\section{Total phenolic content (TPC)}

The TPC of the VN extract was investigated according to the standard protocol [24] using gallic acid as a standard and samples were taken in triplicates. The total phenolic content of the VN extracts was expressed in terms of gallic acid equivalents (mg $\mathrm{GAE} / \mathrm{g}$ extract).

\section{Total flavonoid content (TFC)}

TFC of the VN extracts was determined according to the standard protocol given Kumar and Karakumaran [25]. All samples were taken in triplicate using quercetin as a standard. The total flavonoid content was expressed as quercetin equivalents ( $\mathrm{mg} \mathrm{QE} / \mathrm{g}$ extract).

\section{HCEC culture}

HCEC were cultured in Dulbecco's modified Eagle's medium DMEM/ Hams F12 (1:1) (Himedia/Gibco) that was supplemented with $10 \%$ heat-inactivated FBS and antibiotic-antimycotic solution and maintained at $37^{\circ} \mathrm{C}$ in a humidified atmosphere with $5 \% \mathrm{CO}_{2}$.

\section{Cell viability assay}

For evaluating the cell viability and proliferation of HECE cells, MTT (3[4, 5-dimethylthiazol-2-yl]-2, 5-diphenyl tetrazolium bromide; SigmaAldrich) assay was used. Only viable cells can reduce MTT to insoluble purple formazan. The MTT assay was performed according to the manufacturer instructions. For MTT assay, cells were cultured in 96well plate at a density of $5 \times 10^{3}$ cells per for $24 \mathrm{~h}$. Then, the medium was supplemented with different concentrations $(12.5-200 \mu \mathrm{g} / \mathrm{ml})$ of VN extracts and incubated for $48 \mathrm{~h}$. After which, MTT solution was added and incubated for $4 \mathrm{~h}$ at $37^{\circ} \mathrm{C}$ in the dark. The formazan crystals that formed were solubilized with DMSO addition, and the absorbance was read at $570 \mathrm{~nm}$ using multimode microplate reader (FluoSTAR Omega, BMG Labtech, Ortenberg, Germany). The cell viability was expressed as the percentage of the control.

\section{UVC source and irradiation}

UVP-2000 ultraviolet crosslinker was used for UVC irradiation. Cells were irradiated at a dose of $200 \mathrm{~J} / \mathrm{m}^{2}$ of wavelength $254 \mathrm{~nm}$ and post
$1 \mathrm{~h}$; cells were incubated with aqueous and ethanol extracts of VN leaves at a concentration of $12.5 \mu \mathrm{g} / \mathrm{ml}$ followed by MTT assay

\section{Wound healing assay}

To evaluate the migration of HCEC, wound healing assay was performed. Briefly, HCEC were seeded onto 6-well plate and expanded them to reach up to $80 \%$ confluency. A scratch was made using $200 \mu \mathrm{l}$ microtip after discarding the media followed by phosphate buffered saline (PBS) wash. The media supplemented with different concentration $(12.5$ and $200 \mu \mathrm{g} / \mathrm{ml})$ of $\mathrm{VN}$ extracts and cells were incubated at $37^{\circ} \mathrm{C}$. Images were taken under an inverted microscope (Carl Zeiss, Germany) pre- and post-treatment. Scratch area was analyzed using ZEN software, and the data were represented as percentage wound closure. The experiment was performed using triplicates.

\section{Measurement of ROS production}

The levels of ROS were analyzed using 2', 7'-9 dichlorodihydrofluorescein diacetate (DCF-DA). To analyze the ROS production, HCEC after UVC irradiation at a wavelength $254 \mathrm{~nm}$ and dose $200 \mathrm{~J} / \mathrm{m}^{2}$ and plant extract treatment $(12.5 \mu \mathrm{g} / \mathrm{ml})$ were washed twice with PBS and then incubated with $10 \mu \mathrm{M}$ DCF-DA for $20 \mathrm{~min}$. Post incubation cells were analyzed using flow cytometer, with an excitation wavelength of $488 \mathrm{~nm}$ and an emission wavelength of $530 \mathrm{~nm}$. Data analysis was based on 5,000 detected events using Guava 2.6 software.

\section{Statistical analysis}

The experiment was done in triplicates and data were represented as mean \pm standard deviation (SD). Data were analyzed using one-way analysis of variance with Dennett post hoc test. Differences of $\mathrm{p} \leq 0.01$ were considered significant.

\section{RESULTS}

Phytochemical screening of VN extracts

The phytochemical composition of the aqueous and ethanol extracts of VN is listed in Table 1 . The result shows that both extracts contain alkaloids, phenol, and flavonoids in high amount. Phytosterols and saponins were found in moderate amount only in ethanol extract.

Table 1: Screening of phytochemicals of Cassia fistula leaf extracts

\begin{tabular}{|c|c|c|}
\hline \multirow[t]{2}{*}{ Tests } & \multicolumn{2}{|c|}{ Vitex negundo extracts } \\
\hline & Aqueous & Ethanol \\
\hline \multicolumn{3}{|l|}{ Alkaloids } \\
\hline Mayer's test & + & + \\
\hline Wagners test & - & - \\
\hline \multicolumn{3}{|l|}{ Carbohydrates and glycosides } \\
\hline Molisch's test & + & - \\
\hline Fehling's test & + & - \\
\hline Legal's test for glycosides & - & + \\
\hline \multicolumn{3}{|l|}{ Saponins } \\
\hline Foam test & - & + \\
\hline \multicolumn{3}{|l|}{ Protein and amino acids } \\
\hline Biuret test & + & + \\
\hline Ninhydrin test & + & + \\
\hline \multicolumn{3}{|l|}{ Phytosterols } \\
\hline Liebermann-Burchard's test & - & + \\
\hline \multicolumn{3}{|l|}{ Phenolics and tannins } \\
\hline Fecl ${ }_{2}$ test & + & + \\
\hline Gelatin test & - & - \\
\hline Lead acetate test & + & + \\
\hline \multicolumn{3}{|l|}{ Flavonoids } \\
\hline Alkaline reagent test & + & + \\
\hline
\end{tabular}

$(+)$ Indicates the presence of the phytocompound and (-) Indicates the absence of phytocompound

\section{Total antioxidant activity}

The TAC was done by phosphomolybdenum assay for VN extract in comparison with that of ascorbic acid as a standard reference. Overall, the ethanol extract showed a much higher antioxidant potential than 
the aqueous extracts which was similar to standard ascorbic acid. There was a dose-dependent increase in the TAC in both ethanol and aqueous extracts (Fig. 1). The antioxidant capacity of the ethanol extract could be corelated to the proportion of phenolic compounds present in the extracts.

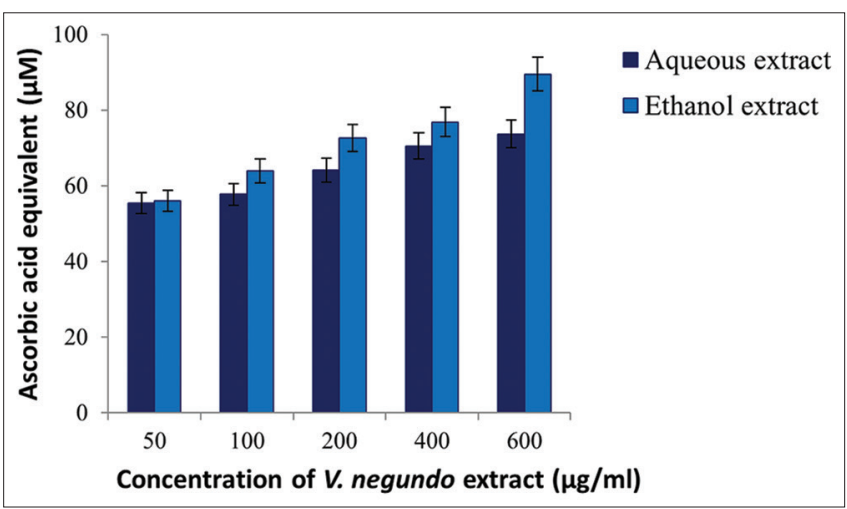

Fig. 1: Total antioxidant activity of Vitex negundo extracts. Ethanol and aqueous extracts were taken at different concentrations

(50-600 $\mu \mathrm{g} / \mathrm{ml})$ and total antioxidant activity was expressed as AAE using ascorbic acid as a standard. Values are expressed as the mean $\pm S D(n=3)$.

DPPH radical scavenging activity

ROS reducing the activity of VN extracts is given in Fig. 2. The study was done based on the ability of the extracts to reduce the stable radical DPPH. The radical scavenging effect of the extract was concentration dependent. We found that aqueous extract had less DPPH reducing activity than the ethanol extracts of VN. Ethanolic extract at $200 \mu \mathrm{g} / \mathrm{ml}$ showed significant activity with $90 \%$ activity followed by 400 and $600 \mu \mathrm{g} / \mathrm{ml}$ when compared to standard ascorbic acid.

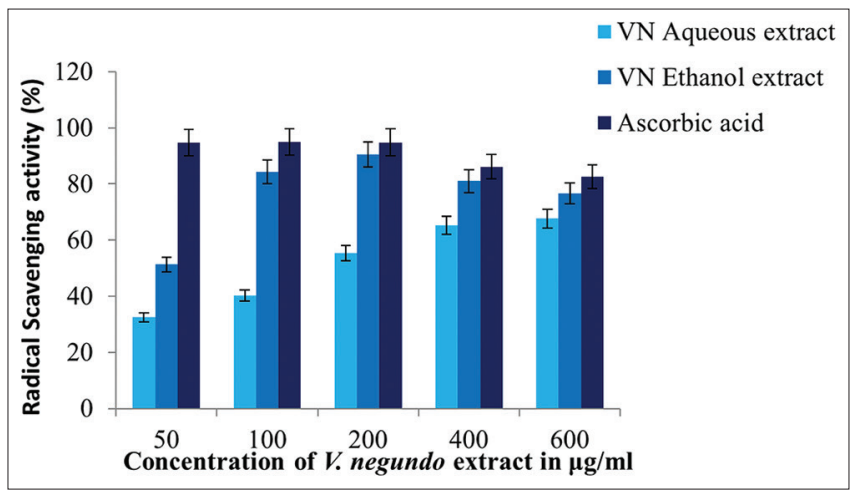

Fig. 2: 1,1-diphenyl-2 picrylhydrazyl radical scavenging activity Vitex negundo extracts. Different concentrations of ethanol and aqueous extracts ranging from 50 to $600 \mu \mathrm{g} / \mathrm{ml}$ were taken for the experiment. Values are expressed as mean $\pm S D(n=3)$. Ascorbic at concentrations $(50-600 \mu \mathrm{g} / \mathrm{ml})$ was used as a standard. $p<0.01$ is considered significant.

Total phenolic and flavonoid content of the VN extracts

Table 2: Total phenolic and flavonoid content of aqueous and ethanol extracts of Vitex negundo extracts

\begin{tabular}{lll}
\hline \multirow{2}{*}{ Test } & \multicolumn{2}{l}{ Vitex negundo leaves } \\
\cline { 2 - 3 } & Aqueous extract & Ethanol extract \\
\hline $\begin{array}{l}\text { Total phenolic content } \\
\text { (mg GAE/g extract)* }\end{array}$ & $20.48 \pm 0.01$ & $32.43 \pm 0.021$ \\
$\begin{array}{l}\text { Total flavonoid content } \\
\text { (mg QE/g extract)* }\end{array}$ & $13.78 \pm 0.571$ & $28.42 \pm 0.002$ \\
\hline
\end{tabular}

*All values are expressed as mean $\pm \mathrm{SD}, \mathrm{n}=3$
To evaluate the potential antioxidant capacity of the extracts from VN leaves, it was essential to determine the polyphenols content in aqueous extract and ethanol extract. The total phenols and flavonoids have been determined for both extracts by spectrophotometric methods, and the results are presented in Table 2 .

Effect of VN extracts on the proliferation of HCEC

The proliferation of HCEC was evaluated by MTT assay after $48 \mathrm{~h}$ posttreatment with different concentrations $(12.5-200 \mu \mathrm{g} / \mathrm{ml})$ of $\mathrm{VN}$ ethanol (VNE) and aqueous extracts (VNA). The results indicated that aqueous and ethanol extracts at a concentration of $200 \mathrm{ug} / \mathrm{ml}$ had no adverse effect on the viability and proliferative ability of HCEC. There was no significant difference between the groups when compared to control in the aqueous group. In the ethanol group, the concentrations 12.5 and $25 \mu \mathrm{g} / \mathrm{ml}$ showed a significant difference compared to control as shown in Fig. 3. Considering the effect of VN extract on the proliferation of HCEC, the concentrations of $12.5 \mu \mathrm{g} / \mathrm{ml}$ of the extracts were used for further experiments.

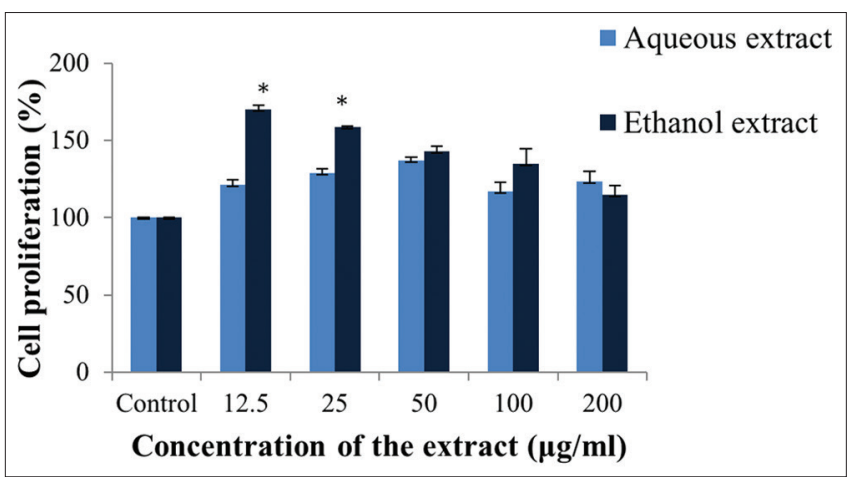

Fig. 3: Effect of Vitex negundo aqueous and ethanol extract on human corneal epithelial cells proliferation. HCEC were cultured with various concentrations of extracts and number of viable cells was quantified by MTT assay for $48 \mathrm{~h}$. Data are represented as mean $\pm S D ;(n=3), p<0.01$ is considered significant.

Effect of VN extracts against UVC-induced injury in HCEC

To investigate the protective effects of VN leaf extracts, the UVC irradiated cells were incubated with aqueous and ethanol extracts at a concentration of $12.5 \mu \mathrm{g} / \mathrm{ml}$ followed by MTT assay. The results showed that UVC irradiation on HCEC decreased the cell viability by $47 \%$ which was then regained to $73.22 \%$ and $82.07 \%$ by aqueous and ethanol extracts. When compared, the ethanol extract found to be more effective in protecting HCEC from UV-induced injury (Fig. 4).

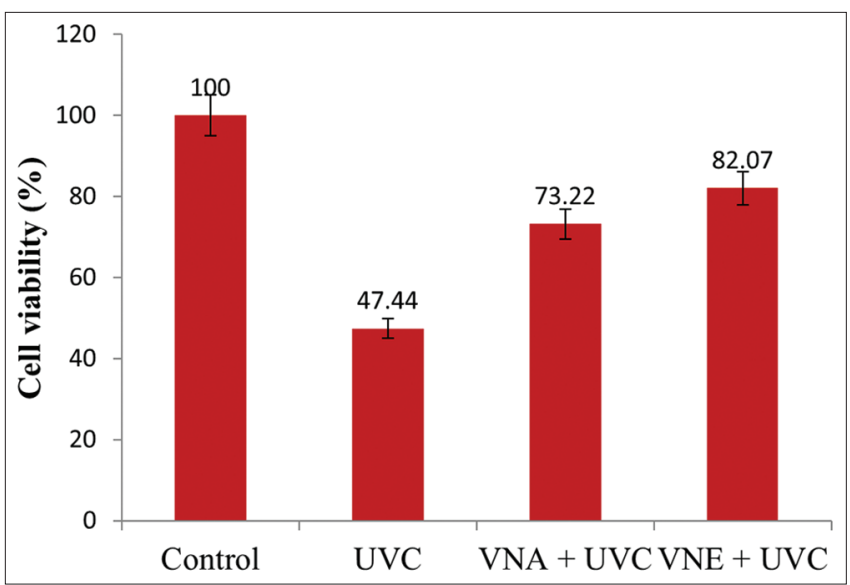

Fig. 4: Effect of Vitex negundo leaf extracts on ultraviolet light C irradiated human corneal epithelial cells. HCEC were irradiated with Ultraviolet $C$ radiation at a dose of $200 \mathrm{~J} / \mathrm{m}^{2}$, and after $1 \mathrm{~h}$, cells were incubated with aqueous and ethanol extracts of VN $(12.5 \mu \mathrm{g} / \mathrm{ml})$ extracts followed by MTT assay. Data are represented as mean $\pm S D(n=3)$. 


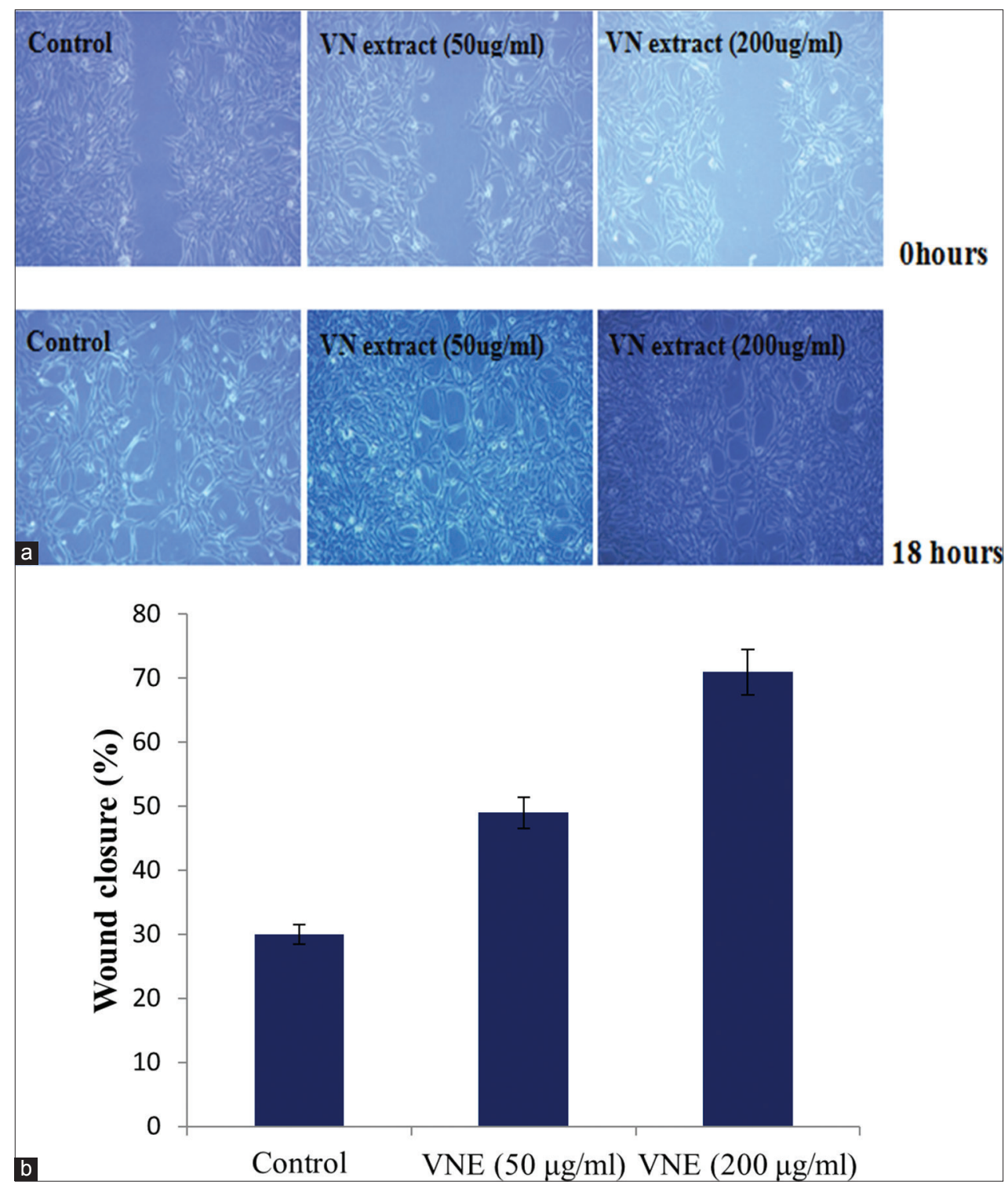

Fig. 5: (a) Representative micrographs pictures of human corneal epithelial cells scratch assays immediately after the scratches, and in time (18 h) course of the experiments. Scale bar, $100 \mu \mathrm{m}$.(b) Cellular proliferation response elicited by Vitex negundo (VN) ethanol extracts on human corneal epithelial cells (HCEC) was evaluated using in vitro cell migration assay and wound closure percentage was calculated. HCEC were seeded onto six-well plates, and after confluence, a scratch was created in the center of the well and cells were treated with VN ethanol extracts. Treatment with extracts promoted proliferation and migration of epithelial cells to the scratch area

\section{VN promotes HCEC migration}

Effect of VN extracts on the migration of HCEC was studied by wound healing assay in confluent culture. The migration rate of HCEC was evaluated for $18 \mathrm{~h}$ after creating a wound in the cultures with supplementation of VN extracts at concentrations 50 and $200 \mu \mathrm{g} / \mathrm{ml}$ along with control. The representative images of migration of the HCEC in the cultures supplemented with extracts and control culture at $0 \mathrm{~h}$ and $18 \mathrm{~h}$ after making wound are shown in Fig. 5. It was found that the wound area recovered faster in the culture supplemented with extracts than without the extracts due to the faster migration of HCEC. With the increase in the concentration of the extract $(200 \mu \mathrm{g} / \mathrm{ml})$, reepithelialization of corneal epithelium was found to be enhanced during wound healing. The percentage wound closure at $18 \mathrm{~h}$ was found to be $40 \%$ and $70.99 \%$ for 50 and $200 \mu \mathrm{g} / \mathrm{ml}$ concentration of the extract.

\section{Inhibition of ROS production in HCEC in vitro by VN extracts}

The inhibition of intracellular ROS production in HCEC by VN extracts was analyzed using DCF-DA fluorescence. After UV irradiation at a wavelength of $254 \mathrm{~nm}$ and a dose of $200 \mathrm{~J} / \mathrm{m}^{2}$, plant extracts $(12.5 \mu \mathrm{g} / \mathrm{ml})$ were added to the cell cultures followed by incubation for $30 \mathrm{~min}$. The extracellular ROS was evaluated with flow cytometry, the mean intensities of fluorescence significantly increased after UV irradiation compared with the control. The extracts significantly inhibited the amount of extracellular ROS produced after UV irradiation. Ethanol extract showed higher inhibition rate than the aqueous extract as shown in Fig. 6a. The graphical representation of the data is given in Fig. 6b.

\section{DISCUSSION}

VN leaves are used in traditional medicine due to its anti-inflammatory, analgesic, and anti-itching properties for internal and external application [26]. It is used conventionally in the treatment of eyedisease, toothache, inflammation, leukoderma, skin-ulcers, in catarrhal fever, rheumatoid arthritis, gonorrhea, and bronchitis [27]. However, its potential to protect the HCEC from UV induced oxidative stress has not been studied, and very little is known about the cytotoxic and protective effects of VN extracts on HCEC. This is the first study to evaluate the use of VN extracts in protecting HCEC and its effects in enhancing cell migration in vitro and its application in corneal damage. 


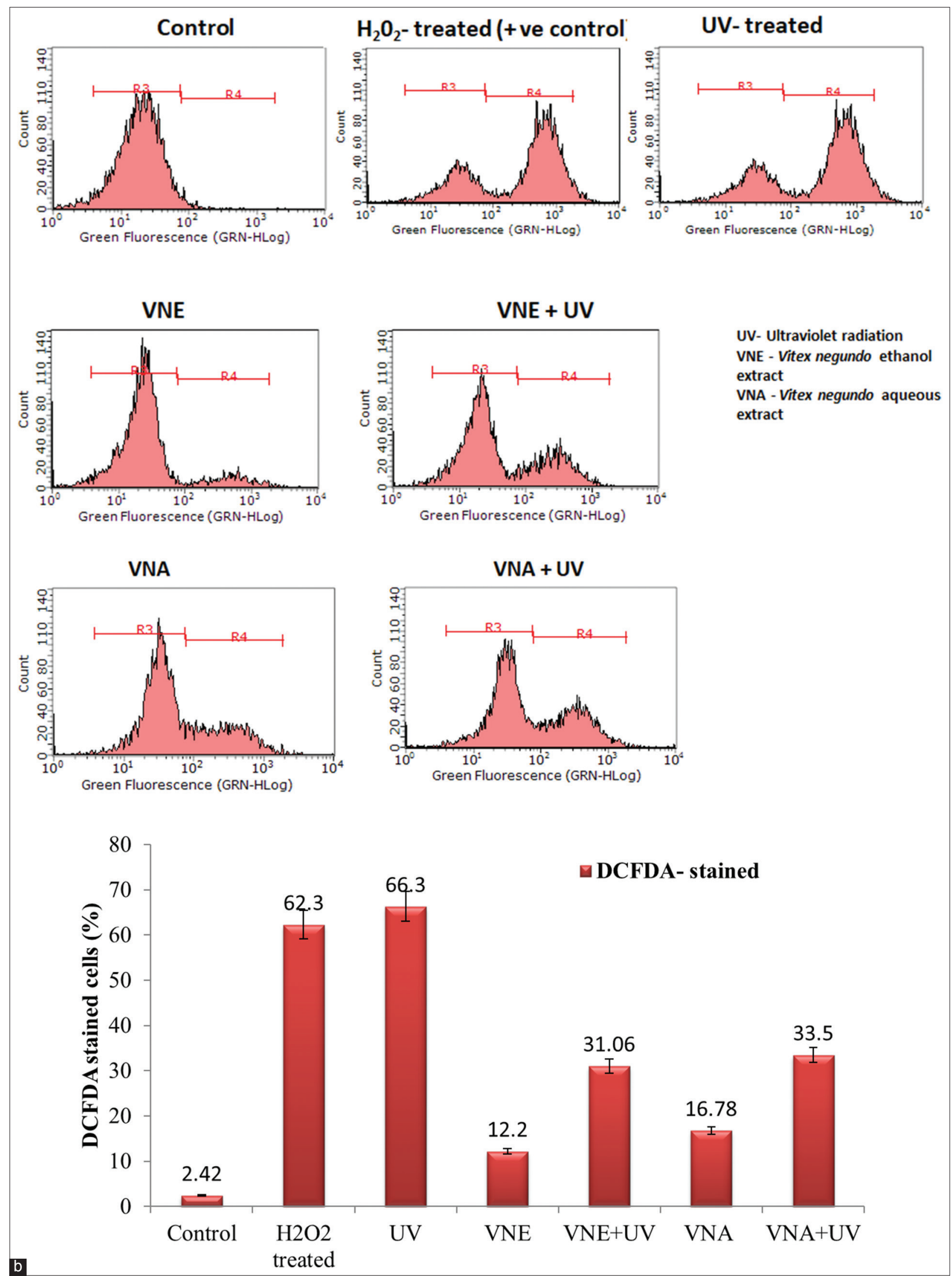

Fig. 6: (a) The levels of extracellular reactive oxygen species measured by dichlorodihydrofluorescein diacetate and flow cytometry. Representative figures showing the inhibition of reactive oxygen species production by the plant extracts with concentration $(12.5 \mu \mathrm{g} / \mathrm{ml})$ against irradiation of UV light $\left(254 \mathrm{~nm}\right.$ and $\left.200 \mathrm{~J} / \mathrm{m}^{2}\right)$ in human corneal epithelial cells. The experiment was performed in triplicates $(\mathrm{n}=3)$.

(b) Graph showing the inhibition of reactive oxygen species production by the plant extracts at concentrations $(12.5 \mu \mathrm{g} / \mathrm{ml}) \mathrm{against}$ irradiation of Ultraviolet C $\left(254 \mathrm{~nm}\right.$ and $\left.200 \mathrm{~J} / \mathrm{m}^{2}\right)$ in HCEC. Data represented as percentage dichlorofluorescein diacetate stained cell count versus treatment; mean $\pm S D(n=3)$ 
In the present study, the VN leaf extracts were screened for their phytochemicals and antioxidant activity. Our study reveals that the extracts have significant antioxidant potential with the presence of prominent phytochemical such as alkaloids, flavonoids, carbohydrates, and proteins. Antioxidant properties in the extracts can be exploited for their use in ayurvedic drug formulations and can be used for combating free radicals, eye diseases, and skin diseases. Total antioxidant activity, DPPH radical scavenging, total phenolics, and flavonoid content of the VNE and VNA leaves were determined. Ethanol extract showed significant antioxidant and free radical scavenging activity than aqueous extract. The total phenolic content was high in the ethanol extract than the aqueous extract, and this property is attributed to their antioxidant activity. This is mainly due to the ability of the extracts to absorb and neutralize the free radicals, to quench the singlet, or triplet oxygen species [28]. The total flavonoid content was also found to be high in ethanol extract than the aqueous extract. Flavonoids are phenolic compounds which are present naturally and are involved in various biological and chemical processes such as free radical scavenging and daily ingestion of polyphenolics have therapeutic effect during carcinogenesis and mutagenesis [29]. Previous reports have shown the presence of phenols, flavonoids, terpenoids, and carbohydrates in VN extracts also, high phenolic and flavonoid content were reported in VN [30,31].

In the present study, the effect of the VN extracts on the cell viability and cell migration was studied. Furthermore, the effect of these extracts on protecting the HCEC from ROS production during UV-induced damage was also checked. Both aqueous and ethanol extracts did not exert any cytotoxic effects on HCEC. This shows that the extract can be effectively and safely used for therapeutic or prophylactic purposes during ocular surface disorders. The effect of VN extracts was studied on the in vitro migration of HCEC to understand the potential use of these extract in corneal epithelial wound healing as a therapeutic agent. It was found that the supplementation the VN ethanol extracts at concentration 50 and $200 \mu \mathrm{g} / \mathrm{ml}$ significantly enhanced the migration of HCEC after $18 \mathrm{~h}$ of wounding. Faster re-epithelialization was seen with an increase in concentration. Previous studies have reported that VN aqueous and ethanol extracts exhibited strong wound healing properties in Wistar rats in experimentally induced excision and incision wound [32].

Overexposure to UV radiation is one of the most common causes of radiation injury to the eye which is an associated risk factor during human corneal damage [33]. UV-induced damages in the eye lead to clinical conditions such as photokeratitis, pterygium, UV keratitis, and clinical droplet keratopathy [34,35]. Therefore, studying a protective agent is important in developing better remedial strategies for corneal cell damage. Our findings suggest that UVC radiation at a dose $200 \mathrm{~J} / \mathrm{m}^{2}$ decreased the cell viability and induced production of ROS significantly which suggests that UV light especially UVC, can have a harmful impact on the corneal surface. Among the evaluated extracts, the ethanol extract showed protective activity on HCEC from oxidative stress induced by UV-irradiation by maintaining the cell viability. Interestingly, the ethanol extracts could effectively inhibit the ROS produced after UVC irradiation than the aqueous extracts. This correlates to the increased antioxidant activity due to the presence of antioxidant enzymes in the extracts. Similar studies showed that the mixture of medicinal plant extracts protected HCEC from blue light-induced oxidative stress by inhibition of ROS production [36]. Reports also confirm that VN has a role in the modulating cellular events such as cell cycle, apoptosis, motility of sperms, and polycystic ovary disease [37].

To sum up, the VN extracts have good antioxidant activity and contain phytocompounds that enhance HCEC migration and were effective in protecting HCEC from UV induced damage by inhibiting ROS production.

\section{CONCLUSION}

Taken together, our results indicate that UVC radiation $(254 \mathrm{~nm})$ can induce oxidative damage to the corneal epithelium and that VN extracts are effective in decreasing ROS production due to their high antioxidant activities. These findings can be extrapolated to elucidate the pathogenesis and develop treatments for eye diseases. Several antioxidants having anti-inflammatory and antioxidant property are in use for topical or systemic application during clinical conditions of eye diseases. Since VN extracts exhibited potent efficacy in the treatment of UVC-induced oxidative stress in this study, it may be effective in the treatment of various oxidative stress-induced ocular surface diseases such as photokeratitis and dry eye. Further studies are needed to validate the anti-inflammatory and antioxidant markers involved during oxidative stress in HCEC.

\section{ACKNOWLEDGMENTS}

Authors would like to acknowledge the financial support rendered by Yenepoya (Deemed to be University). Authors acknowledge Ms. Megha Nair for her help in statistical analysis.

\section{AUTHORS' CONTRIBUTIONS}

Deeksha $\mathrm{K}$ conceived, designed and performed the experiments, analyzed the data and wrote the paper. Dr. Cynthia Arunachalam provided the nurturing environment and intellectual insights.

\section{DECLARATION OF INTEREST}

All authors have none to declare.

\section{REFERENCES}

1. Zigman S. Ocular light damage. Photochem Photobiol 1993;57:1060-8.

2. Tenkate TD. Occupational exposure to ultraviolet radiation: A health risk assessment. Rev Environ Health 1999;14:187-209.

3. Halliwell B, Gutteridge JM. Free radicals, other reactive species, and disease. Free Radic Biol Med 1999;3:617-783.

4. Young S, Sands J. Sun and the eye: Prevention and detection of lightinduced disease. Clin Dermatol 1998;16:477-85.

5. Le Belle JE, Orozco NM, Paucar AA, Saxe JP, Mottahedeh J, Pyle AD, et al. Proliferative neural stem cells have high endogenous ROS levels that regulate self-renewal and neurogenesis in a PI3K/Akt-dependant manner. Cell Stem Cell 2011;8:59-71.

6. Limoli CL, Giedzinski E. Induction of chromosomal instability by chronic oxidative stress. Neoplasia 2003;5:339-46.

7. Kryston TB, Georgiev AB, Pissis P, Georgakilas AG. Role of oxidative stress and DNA damage in human carcinogenesis. Mutat Res-Fund Mol M 2011;711:193-201.

8. Carubelli R, Nordquist RE, Rowsey JJ. Role of reactive oxygen species in corneal ulceration. Effect of hydrogen peroxide generated in situ. Cornea 1990;9:161-9.

9. Aqil F, Ahmed I, Mehmood Z. Antioxidant and free radical scavenging properties of twelve traditionally used Indian medicinal plants. Turk J Biol 2006;30:177-83.

10. Acharya D, Shrivastava A. Indigenous Herbal Medicines: Tribal Formulations and Traditional Herbal Practices. Jaipur, India: Aavishkar Publishers Distributor; 2008. p. 440.

11. Singh P, Mishra G, Srivastava S, Srivastava S, Sangeeta S, Jha KK, et al. Phytopharmacological review of Vitex negundo (Sambhalu). Pharmacogyonline 2011;2:1355-85.

12. Badgujar N, Mistry K, Patel J. V. negundo L. camara and B. variegata plants leaf extract exhibit considerable in vitro antioxidant and anticancer activities. Int J Pharm Pharm Sci 2017;9:227-32.

13. Prasad EM, Mopuri R, Islam MS, Kodidhela LD. Cardioprotective effect of Vitex negundo on isoproterenol-induced myocardial necrosis in Wistar rats: A dual approach study. Biomed Pharmacother 2017;85:601-10

14. Kumar M, Dandapat S, Sinha MP. Hepatoprotective activity of Adhatoda vasica and Vitex negundo leaf extracts against carbon tetrachloride-induced hepatotoxicity in rats. Adv Biol Res 2015;9:242-6.

15. Siddiqui S, Saify ZS, Jamali KS, Tufail P, Kanwal A, Kamal A, Khan F. Neuroprotective capabilities of Vitex negundo in primary hippocampal neurons. Pak J Pharm Sci 2018;2018:31.

16. Meena AK, Singh U, Yadav AK, Singh B, Rao MM. Pharmacological and phytochemical evidences for the extracts from plants of the genus Vitex - A review. Int J Pharm Clin Res 2010;2:1-9.

17. Sushruta SS. Dalhana Comm. Nibandhasangraha. Varanasi: Chowkhambha Orientalia; 2002

18. Nighantu BB. In: Pandey SG, editor. Hindi Comm - Krishna Chandra Chunekar. Varanasi: Chaukhambha Bharati Academy; 1990. p. 99-100. 
19. Nighantu KK. Pathyapathya Vibodhakah. Oushadihi varga. Varanasi: Chaukhambha Orientalia; 1979. p. 128

20. Parekh J, Chanda SV. In vitro antimicrobial activity and phytochemical analysis of some Indian medicinal plants. Turk J Biol 2007;31:53-8.

21. Sakat S, Juvekar AR, Gambhire MN. In vitro antioxidant and antiinflammatory activity of methanol extract of Oxalis corniculata Linn. Int J Pharm Pharm Sci 2010;2:146-55.

22. Prieto P, Pineda M, Aguilar M. Spectrophotometric quantitation of antioxidant capacity through the formation of a phosphomolybdenum complex: Specific application to the determination of Vitamin E. Anal Biochem 1999;4:269.

23. Rajan S, Gokila M, Jency P, Brindha P, Sujatha RK. Antioxidant and phytochemical properties of Aegle marmelos fruit pulp. Int J Curr Pharm Res 2011;3:65-70.

24. Kumar G, Karthik L, Bhaskara RKV. Antibacterial activity of aqueous extract of Calotropis gigantea leaves-an in vitro study. Int J Pharm Sci Rev Res 2010;4:141-4

25. Kumaran A, Karakumaran J, In vitro antioxidant activities of methanol extracts of five Phyllanthus species from India. LWT-Food Sci Technol 2007;40:344-52.

26. Gunatillake S. Nika in Osuturu Visituru 3. Colombo, Sri Lanka: Department of Ayurveda, Sri Lanka; 1994. p. 144-9.

27. Chitra V, Sharma S, Kayande N. Evaluation of anticancer activity of Vitex negundo in experimental animals: An in vitro and in vivo study. Int J Pharm Tech Res 2009;1:1485-9.

28. Saklani S, Mishra AP, Chandra H, Atanassova MS, Stankovic M, Sati B, et al. Comparative evaluation of polyphenol contents and antioxidant activities between ethanol extracts of Vitex negundo and Vitex trifolia L. leaves by different methods. Plants 2017;6:45.

29. Lazaro ML. Distribution and biological activities of the flavonoid Luteolin. Mini Rev Med Chem 2009;9:31-59.

30. Sastri BN. The Wealth of India, A Dictionary of Raw material and Industrial Products. New Delhi, India: Council of Scientific and Industrial Research; 1950. P. 285-93.

31. Prasanna K, Karthikeyan V. Preliminary phytochemical, total phenolics and flavonoid content analysis of Vitex negundo and Calatropis gigantea leaf ethanolic extracts. J Chem Pharm Res 2015;7:282-5.

32. Talekar YP, Das B, Paul T, Talekar DY, Apte KG, Parab PB. Wound healing potential of Vitex negundo Linn in experimental animals. Int $\mathrm{J}$ Pharm Sci 2012;4:543-6.

33. Kolozsvári L, Nógrádi A, Hopp B, Bor Z. UV absorbance of the human cornea in the 240- to 400-nm range. Invest Ophthalmol Vis Sci 2002; $43: 2165-8$

34. Lennikov A, Kitaichi N, Fukase R, Murata M, Noda K, Ando R, et al. Amelioration of ultraviolet-induced photokeratitis in mice treated with astaxanthin eye drops. Mol Vis 2012;18:455-64.

35. Chang SW, Chou SF, Chuang JL. Mitomycin C potentiates ultravioletrelated cytotoxicity in corneal fibroblasts. Cornea 2008;27:686-92.

36. Lee JB, Kim SH, Lee SC, Kim HG, Ahn HG, Li Z, et al. Blue lightinduced oxidative stress in human corneal epithelial cells: Protective effects of ethanol extracts of various medicinal plant mixtures. Invest Ophthalmol Vis Sci 2014;55:4119-27.

37. Gill BS, Mehra R, Kumar S. Vitex negundo and its medicinal value. Mol Biol Rep 2018;11:1-10 